\title{
A Combination of PG490 and Lipopolysaccharide Induce Apoptosis through Activation of Casapase-3 and Down- regulation of cIAP1 and XIAP in Human Astroglioma Cell
}

\author{
Tae-Jin Lee, Kyung-Jin Woo, Jong-Wook Park and Taeg Kyu Kwon
}

Department of Immunology and Chronic Disease Research Center and Institute for Medical Science, School of Medicine, Keimyung University, Daegu, South Korea

\begin{abstract}
Background: Malignant gliomas are the most common primary tumors in the central nervous system. Methods: We investigated the combined effect of PG490 and LPS on the induction of the apoptotic pathway in human astroglioma cells. Results: Treatment of U87 cells with combination of $50 \mathrm{nM}$ of PG490 and $50 \mu \mathrm{g} / \mathrm{ml}$ of LPS resulted in increased internucleosomal DNA fragmentation, cleavage of PLC-y1, and downregulation of cIAP1 and XIAP. The combination of LPS and PG490 treatment-induced apoptosis is mediated through the activation of caspase, which is inhibited by the caspase inhibitor, z-VAD-fmk. Also, release of cytochrome c was found in PG490 and LPScotreated U87 cell. Conclusion: Taken together, combination of PG490 and LPS appears to be a potent inducer of apoptosis in astrogliaoma cells, and might have some benefit in the treatment of glioma patients. (Immune Network 2005;5(2):99-104)
\end{abstract}

Key Words: LPS, PG490, apoptosis, astroglioma

\section{Introduction}

LPS is a component of Gram negative bacterial cell walls, which has a biological activity and plays a critical role in immune and inflammatory responses. LPS is a trigger of tumor necrosis factor (TNF)- $\mathrm{a}$ in the central nerve system and induces apoptosis in the rat brain (1). In human neuroblastoma SH-SY5Y cells, S-nitroso-N-acetylpenicillamine (SNAP), a nitric oxide (NO)-donor, caused cell death accompanying nucleosomal DNA fragmentation (2). Also, LPS induced the secretion of TNF-a and the production of nitric oxide in mouse macrophages (3). Treatment with shiga toxin 1 (Stx1) and LPS resulted in the rapid onset of cell death compared to LPS alone treatment, indicating a slightly faster induction of cell death in combination of Stx1 and LPS-treated cells (4). We hypothesized that the combined treatment with LPS as an apoptotic trigger and a chemothera-

Correspondence to: Taeg Kyu Kwon, Department of Immunology, School of Medicine, Keimyung University, 194 Dongsan-dong, Junggu, Daegu 700-712, South Korea. (Tel) +82-53-250-7846, (Fax) +82-53-250-7074, (E-mail)kwontk@dsmc.or.kr

This work was supported by grants to Taeg Kyu Kwon from the MRC Program of the Korea Science and Engineering Foundation (No. R13-2002-028-03001-0). peutic agent would increase cell death activity compared with single-agent treatment.

PG490 (triptolide) is a diterpenoid triepoxide compound derived from Chinese herb Tripterygium wilfordii Hook F, which possesses potent anti-inflammatory and immunosuppressive properties $(5,6)$. Recent studies show that triptolide inhibits mitogen- induced lymphocyte proliferation and has immunosuppressive effects in skin allograft transplantation $(7,8)$. Further reports demonstrate that triptolide possesses antiproliferative activity against L1210 and P388 mouse leukemia cells and suppresses colony formation of breast cancer cell lines $(9,10)$. Also, previous studies have shown that PG490, immunomodulating agent, enhances chemotherapy-induced apoptosis (11-13).

The current study was designed to investigate a combinatory cytotoxic effect of PG490 and LPS on human glioma cells. Therefore, we examined the mechanism of antitumor activity of combined PG490 and LPS in human glioblastoma cells. We have shown that combination of PG490 and LPS-induced apoptosis is mediated by caspase- 3 activation and down-regulation of cIAP1 and XIAP.

\section{Materials and Methods}

Cells and materials. Human astroglioma U87 cells were 
obtained from the American Type Culture Collection (ATCC). Cells were cultured in DMEM supplement with $10 \%$ fetal bovine serum, 100 units $/ \mathrm{ml}$ penicillin, and $100 \mathrm{\mu g} / \mathrm{ml}$ streptomycin (Gibco). PG490 (Alexis) and LPS (Sigma-Aldrich) was directly added to cell cultures at the indicated concentrations. Anti-cIAP1, anti-cIAP2, anti-Bcl-2, anti-Bcl-xL, anti-Bax, anti-cytochrome $c$, and anti-HSP70 antibodies were purchased from Santa Cruz Biotechnology Inc. Antibodies against specific proteins were obtained from the following suppliers: XIAP from R\&D systems, and benzyloxycarbony-Val-Ala-Asp-fluoromethyl ketone (z-VADfmk) from Biomol.

Western blotting. Cellular lysates were prepared by suspending $1.5 \times 10^{6}$ cells in $100 \mathrm{pl}$ of lysis buffer (137 $\mathrm{mM} \mathrm{NaCl}, 15 \mathrm{mM}$ EGTA, $0.1 \mathrm{mM}$ sodium orthovanadate, $15 \mathrm{mM} \mathrm{MgCl}_{2}, 0.1 \%$ Triton X-100, $25 \mathrm{mM}$ MOPS, 100uM phenylmethylsulfonyl fluoride, and $20 \mu \mathrm{M}$ leupeptin, adjusted to $\mathrm{pH} 7.2$ ). The cells were disrupted by sonication and extracted at $4^{\circ} \mathrm{C}$ for 30 min. Proteins were electrotransferred to Immobilon-P membranes (Millipore Corporation). Specific proteins were detected with an ECL Western blotting kit, according to the manufacturer's instructions.

$D N A$ fragmentation assay. After treatment with drugs, U87 cells were lysed in buffer containing $10 \mathrm{mM}$ Tris (pH 7.4), $150 \mathrm{mM} \mathrm{NaCl}, 5 \mathrm{mM}$ EDTA, and $0.5 \%$ Triton X-100 for $30 \mathrm{~min}$ on ice. Lysates were vortexed and cleared by centrifugation at 10,000 $\mathrm{g}$ for 20 min. Fragmented DNA in the supernatant was extracted with an equal volume of neutral phenol: chloroform:isoamyl alcohol mixture $(25: 24: 1)$, and analyzed electrophoretically on $2 \%$ agarose gels containing $0.1 \mu \mathrm{g} / \mathrm{ml}$ ethidium bromide.

Caspase-3 activity assay. To evaluate caspase-3 activity, cell lysates were prepared following treatment with LPS and triptolide. Assays were performed in 96-well microtitre plates by incubating $20 \mu \mathrm{ug}$ cell lysates in
(A)
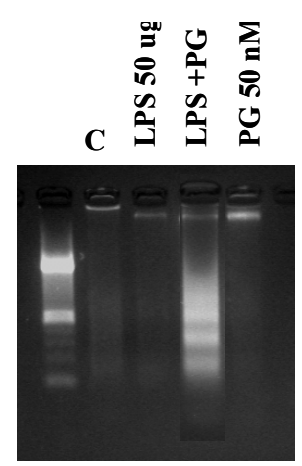

(C)

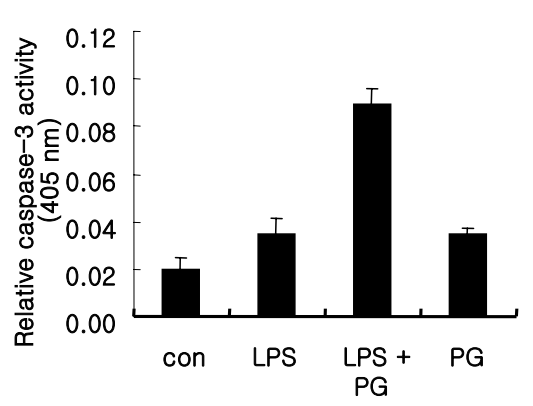

(B)



(D)

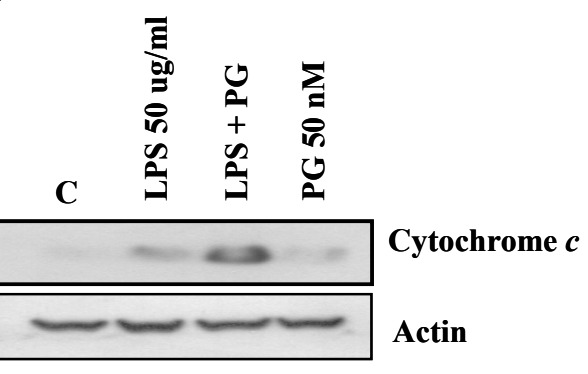

Figure 1. Effect of combined PG490 and LPS on DNA fragmentation, caspase-specific cleavage of PLC-v1, caspase-3 activity, and cytochrome $c$ release. (A) To analyze fragmentation of genomic DNA, cells were treated for $24 \mathrm{hr}$ with the indicated concentrations of PG490 $(50 \mathrm{nM})$ and LPS $(50 \mathrm{\mu g} / \mathrm{ml})$. Fragmented DNA was extracted and analvzed on a $2 \%$ agarose gel. (B) Cells were treated with the indicated concentrations of triptolide. Equal amounts of cell lysates (40 pg) were subjected to electrophoresis and analyzed by Western blotting to assess the levels of caspase-3 and PLC-v1. Proteolytic cleavage of PLC-v1 is specified with arrows. (C) Enzymatic caspase-3 activity was determined by incubating $20 \mathrm{\mu g}$ total protein with $200 \mathrm{\mu M}$ chromogenic substrate (DEVD-pNA) in a $100 \mathrm{pl}$ assay buffer for $2 \mathrm{hr}$ at $37^{\circ} \mathrm{C}$. (D) Cytosolic extracts were prepared as described under Materials and Methods. Thirty micrograms of cytosolic protein was resolved on $12 \%$ SDS-PAGE and then transferred to nitrocellulose, and probed with specific anti-cytochrome $c$ antibody, or with anti-actin antibody to serve as control for the loading of protein level. 
100ul reaction buffer (1\% NP-40, $20 \mathrm{mM}$ Tris-HCl, $\mathrm{pH} 7.5,137 \mathrm{mM} \mathrm{NaCl}, 10 \%$ glycerol) containing $5 \mu$ M DEVD-pNA (a caspase-3 substrate). Lysates were incubated at $37^{\circ} \mathrm{C}$ for $2 \mathrm{hr}$. Absorbance at $405 \mathrm{~nm}$ was measured with a spectrophotometer.

Analysis of cytochrome c release. Cells $\left(2 \times 10^{6}\right)$ were harvested, washed once with ice-cold phosphate buffered saline, and gently lysed for $2 \mathrm{~min}$ in 80ul ice- cold lysis buffer $(250 \mathrm{mM}$ sucrose, $1 \mathrm{mM}$ EDTA, $20 \mathrm{mM}$ Tris- $\mathrm{HCl}, \mathrm{pH}$ 7.2, $1 \mathrm{mM}$ DTT, $10 \mathrm{mM} \mathrm{KCl}, 1.5 \mathrm{mM}$ $\mathrm{MgCl}_{2}, 5 \mu \mathrm{g} / \mathrm{ml}$ pepstatin A, $10 \mu \mathrm{g} / \mathrm{ml}$ leupeptin, and $2 \mu \mathrm{g} / \mathrm{ml}$ aprotinin). Lysates were centrifuged at $12,000 \mathrm{~g}$ at $4^{\circ} \mathrm{C}$ for $10 \mathrm{~min}$ to obtain the supernatants (cytosolic extracts free of mitochondria) and the pellets (fraction that contains mitochondria).

\section{Results}

Caspase mediates PG490 and LPS-induced apoptosis. We investigated the effect of PG490 and LPS on DNA fragmentation in U87 cells to examine the mechanism of cell death. Whereas LPS or PG490 alone did not caused DNA fragmentation, co-treatment with subcytotoxic concentration of $50 \mathrm{nM}$ of PG490 and 50 $\mathrm{\mu g} / \mathrm{ml}$ of LPS resulted in chromosomal DNA degradation at internucleosomal linkages (Fig. 1A). These results indicated that the combined PG490 and LPS treatment significantly increased apoptosis in U87 cells. To determine the roles of caspase in PG490 and LPS-induced apoptosis, we measured the activity of caspase-3 in U87 cells treated with combination of PG490 and LPS. Caspase-3 is activated by proteolytic processing of the $32-\mathrm{kDa}$ form into two smaller subunits. Caspase-3 activity during PG490 and LPS- induced apoptosis was determined by measuring proenzyme levels using Western blot analysis. As shown in Fig. 1B, cotreatment with PG490 and LPS for 24 $\mathrm{hr}$ resulted in a decrease in pro-caspase-3 levels. To further quantify the proteolytic activity of caspase-3, we performed an in vitro assay, based on the cleavage of DEVD-pNA by caspase-3 into chromophore $p$-nitroanilide (pNA). U87 cells displayed a 2.3-fold increase in DEVD-pNA cleavage after $24 \mathrm{hr}$ exposure to combination of PG490 and LPS compare to LPS or PG490 single treatment (Fig. 1C).

Caspase-3 is one of the key proteases responsible for the cleavage of poly (ADP-ribose) polymerase (PARP), PLC-y1, DNA-dependent protein kinase, protein kinase $\mathrm{C}-\delta(\mathrm{PKC}-\delta)$ and Bax, among other substrates (14-16). PLC-y1 is cleaved into a $60-\mathrm{kDa}$ fragment by in vivo activated caspase-3 (17). Subsequent Western blotting disclosed proteolytic cleavage of PLC-y1 and Bax (Fig. 1B and Fig. 2B). Cytochrome $c$ release was potentiated by co-treatment of LPS and PG490 in U87 cells after 24 hr (Fig. 1D). Modulation of IAP and Bcl-2 protein families in LPS and PG490-induced apoptosis. To determine whether caspase-3 activity in PG490 and LPS-induced apoptosis is associated with the expression levels of caspase inhibitory proteins and Bcl-2 family proteins, we examined the expression of IAP and bcl-2 family proteins in U87 cells treated with PG490 and LPS. As shown in Fig. 2A, treatment of U87 cells with PG490 and LPS for $24 \mathrm{hr}$ resulted in decreased levels of cIAP1 and XIAP, but not cIAP2. A combined treatment does not significantly alter the expression of the Bcl-2 and Bcl-xL. Interestingly, only Bax pro-
(A)

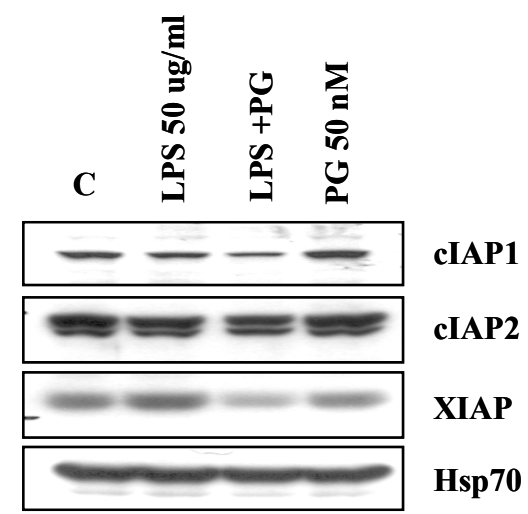

(B)

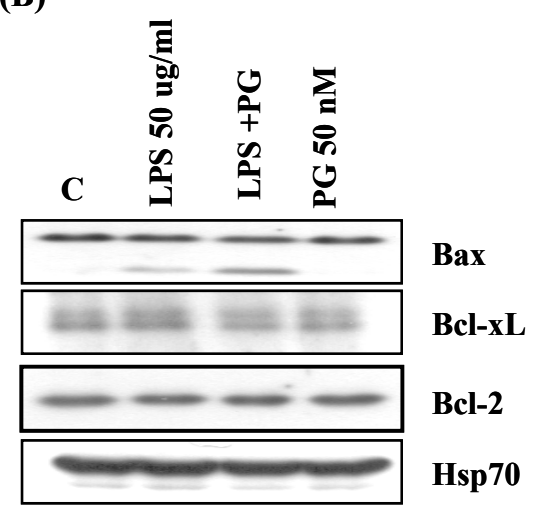

Figure 2. Expression of apoptosis-related proteins in U87 cells following treatment with PG490 and LPS. (A) U87 cells were treated with the indicated concentrations of PG490 and LPS. Equal amounts of cell lysates (40 $\mathrm{pg}$ ) were resolved by SDS-PAGE, transferred to nitrocellulose, and probed with specific antibodies (anti-cIAP1, anti-cIAP2, or anti-XIAP). To confirm equal loading, the blot was stripped of the bound antibody and reprobed with anti-Hsp70 antibody. (B) U87 cells were treated with the indicated concentrations

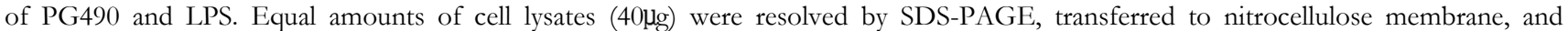
probed with specific antibodies (anti-Bax, anti-Bcl-xL, and anti-Bcl-2). To confirm equal loading, the blot was stripped of the bound antibody and reprobed with anti-Hsp70 antibody. 


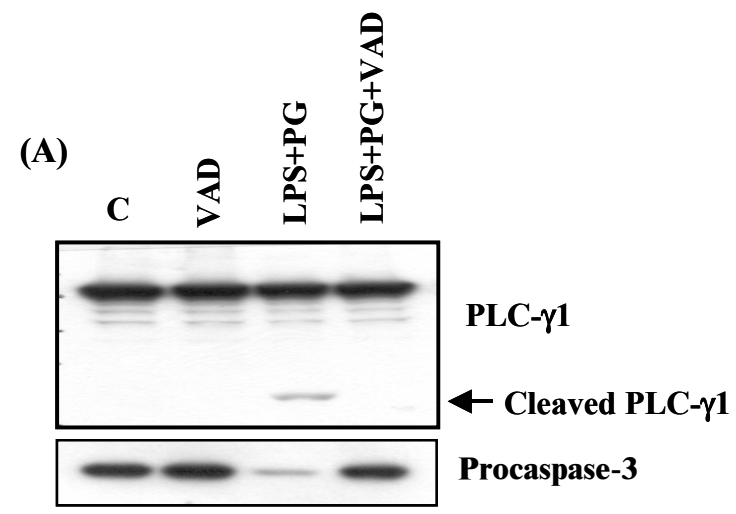

(C)

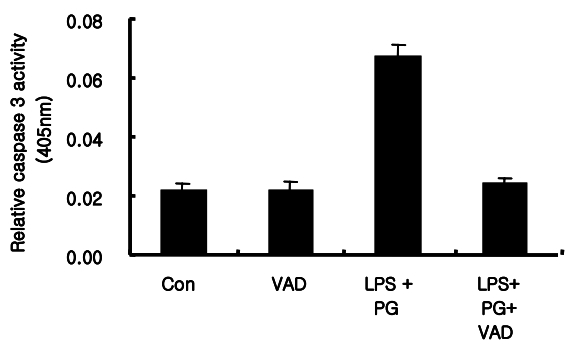

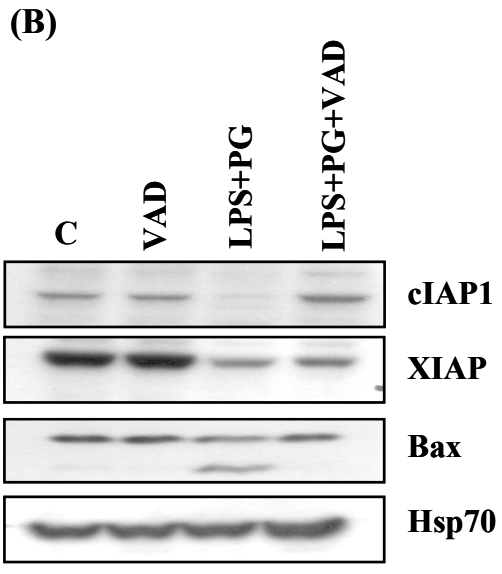

Figure 3. Effects of $\mathrm{z}$-VAD-fmk on combined PG490 and LPS -induced apoptosis. (A) 87 cells were incubated with the indicated concentrations of z-VAD-fmk for $1 \mathrm{hr}$ before treatment with PG490 $(50 \mathrm{nM})$ and LPS $(50 \mu \mathrm{g} / \mathrm{ml})$ for $24 \mathrm{hr}$. Equal amounts of cell lysates (40 $\mathrm{\mu g})$ were resolved by SDS-PAGE, transferred to a nitrocellulose membrane, and probed with anti-caspase-3 and anti-PLC-y1 antibodies. To confirm equal loading, the blot was stripped of the bound antibody and reprobed with anti-Hsp70 antibody. (B) Equal amounts of cell lysates $(40 \mathrm{\mu g})$ were resolved by SDS-PAGE, transferred to nitrocellulose, and probed with specific antibodies (anti-cIAP1, anti -X1AP, and anti-Bax). (C) Caspase activity was determined as described in Fig. 1. Data are presented as means $\pm S D(N=3)$. tein was slightly cleaved in PG490 and LPS-exposed cells (Fig. 2B). These data indicate that elevated caspase-3 activity in PG490 and LPS-treated U87 cells is correlated to down-regulation of cIAP1 and XIAP and cleaved Bax protein.

Effects of $₹-V A D$-fmk on LPS and PG490-induced caspase-3 activation. We examined the consequences of LPS and PG490 treatments on caspase activation in U87 cells treated with a general and potent inhibitor of caspases, z-VAD-fmk. LPS and PG490 strongly stimulated PLC- $y 1$ cleavage, caspase-3 protease activity, down-regulation of cIAP1 and XIAP, and Bax cleavage, which were abolished in cells pretreated with $z$-VAD-fmk (Fig. 3). These results demonstrated that PG490 and LPS-induced apoptosis was mediated by activation of caspase- 3 .

\section{Discussion}

A combination of an immunomodulating agent with an anticancer drug could improve the tumorcidal effect. Previous studies have shown that PG490, immunomodulating agent, enhances chemotherapy-induced apoptosis (11-13). Lee et al. (18) demonstrated that a compound that blocks TNF-a-induced activation of NF- $\mathrm{KB}$ may enhance the cytotoxicity of TNF-a on tumors in vivo. Hui AM et al reported that suppression of NF-kB activation markedly enhances SERM-induced apoptosis, suggesting a role for NF$\mathrm{KB}$ in protecting glioma cells (19). In our previous studies, we have shown PG490 induced apoptosis in human leukemia U937 cells and blocked NF-KB signaling pathway in Raw 264.7 macrophage cells $(20,21)$.

LPS affects a wide range of physiological functions in the central nervous system (CNS). In previous studies, it had been shown that LPS caused cell death in tyrosine hydroxylase-positive neurons in mixed neuron/glia cultures $(22,23)$. Neuronal apoptosis occurring in neuronal degeneration during inflammation can be mediated by TNF-a secreted by microglia (1). Whereas, Cheng YJ et al reported enhancement of TNF-a expression does not trigger apoptosis upon exposure of glial cells to lead and lipopolysaccharide in human glioma U-373MG cells (24). Bhat NR et al reported that the treatment of glial cells with either LPS alone (microglia) or a combination of LPS and interferon-gamma (astrocytes) resulted in an induced production of NO and TNF-a (25). Therefore, we hypothesized that combination of TNF-a and NO inducer as an apoptotic cell death trigger and immunomodulating agent could have stronger antitumor activity than single agent. 
Here, we demonstrated that the combination of LPS and PG490 had a significantly increased cytotoxic activity over that of PG490 or LPS alone in glioma cells. Under the same conditions, PG490 or LPS by itself was not cytotoxic to these cell lines. Also, we have shown that combination of PG490 and LPS treatment induces apoptosis in association with the activation of caspase-3, cleavage of Bax protein, and down-regulation of cIAP1 and XIAP. Recent studies have identified caspases as important mediators of apoptosis induced by various apoptotic stimuli (26). Caspase-3 is an important cell death-inducing protease that cleaves PARP, PLC-y1, and other vital proteins $(17,27,28)$. In our experiments, PG490 and LPS induced caspase-3 activation and PLC-y1 cleavage in association with apoptosis (Fig. 1). Panichakul et al. (12) reported the combined TNF-a and PG490 treatment induces apoptosis which is mediated through caspase- 3 activation in cholangiocarcinoma.

Additionally, we found that inhibition of caspase activation by $z$-VAD-fmk prevents LPS and PG490induced apoptosis (Fig. 3). The cleavage of PLC-y1 was inhibited when the cells were pretreated with caspase inhibitor $z$-VAD-fmk, suggesting that apoptosis induced by the combination of LPS and PG490 involved activation of caspase-3.

Next, we examined the expression level of IAP and $\mathrm{Bcl}-2$ proteins families, which are possible causes for caspase-3 activation in LPS and PG490-cotreated U937 cells. Human IAP proteins, including XIAP, cIAP1, cIAP2, and survivin, are characterized by the presence of one to three copies of the BIR domain, a 70-amino acid motif that bears homology to sequences found in the baculovirus IAP proteins (29). These proteins reportedly block apoptosis due to their function as direct inhibitors of activated effector caspases (caspase-3 and caspase-7). Especially, cIAP1 and cIAP2 inhibit cytochrome $c$-induced activation of caspase-9 (30,31). The Bcl-2 gene family is composed of a group of related genes that either promote or prevent apoptosis (32). Members of the family include genes such as $\mathrm{Bcl}-2$ or $\mathrm{Bcl}-\mathrm{xL}$, which are antiapoptotic, and Bax, which is proapoptotic. Members of the Bcl-2 family of proteins are associated with the mitochondrial membrane and regulate its integrity (32). In our experiments, only proapoptotic Bax protein was cleaved in LPS-treated or combined PG490 and LPS-treated U87 cells, but the other Bcl-2 protein family level did not affected by PG490 and LPS only or combined LPS and PG490 (Fig. 2). The combined PG490 and LPS-induced cleavage of Bax protein and down-regulation of cIAP1 and XIAP were inhibited by caspase inhibitor, indicating that the elevated caspase-3 activity in PG490 and LPS-treated
U87 is correlated with Bax cleavage and down-modulation of cIAP1 and XIAP proteins.

Persistent activation of NF- $\mathrm{KB}$ by $10 \mathrm{ng} / \mathrm{ml}$ of LPS led to the survival of leukemic cells against etoposide (VP16)-induced apoptosis and part of the anti-apoptotic potential of LPS might be caused by NF-KB activation (33). LPS-pretreated cells had lower activity of caspase-3 than cells treated with VP16 alone. In our system, LPS-treated U87 cells showed increased caspase-3 activity (Fig. 1).

LPS is known to block TNF-a-induced apoptosis $(34,35)$. Both TNF-a and LPS activate the NF-kB, but through pathways consisting of dissimilar steps. For example, the inhibitory subunit of NF- $\mathrm{KB}$, IKB $\beta$, is more profoundly affected by LPS than by TNF- $a$, whereas I $\mathrm{kBa}$ is affected equally by both agents $(36,37)$. These mean that NF-kB activation can promote apoptosis or survival, depending on the cellular contents. However, how this transcription factor might contribute to the apoptotic process has remained elusive. Further studies will have to be done to elucidate involvement of NF- $\mathrm{KB}$ signaling pathway.

In summary, we have shown that combination of PG490 and LPS-induced apoptosis was at least in part dependent on caspase-3 activation, PLC-y1 cleavage, increased caspase- 3 activity, and down-regulation of cIAP1 and XIAP.

\section{References}

1. Kim WG, Mohney RP, Wilson B, Jeohn GH, Liu B, Hong JS: Regional differences in susceptibility to lipopolysaccharide-induced neutotoxicity in the rat brain: role of microglia. J Neurosci 20;6309-6316, 2000

2. Kitamura Y, Kamoshima W, Shimohama S, Nomura Y, Taniguchi T: Nitric oxide donor-induced p53-sensitive cell death is enhanced by $\mathrm{Bcl}-2$ reduction in human neuroblastoma cells. Neurochem Int 32;93-102, 1998

3. Xaus J, Comalada M, Valledor AF, Lloberas J, Lopez-Soriano F, Argiles JM, Bogdan C, Celada A: LPS induces apoptosis in macrophages mostly through the autocrine production of TNF-alpha. Blood 95;3823-3831, 2000

4. Harrison LM, Cherla RP, van den Hoogen C, van Haaften WC, Lee SY, Tesh VL: Comparative evaluation of apoptosis induced by Shiga toxin 1 and/or lipopolysaccharides in human monocytic and macrophage-like cells. Microb Pathog 38;63-76, 2005

5. Gu WZ, Brandwein SR: Inhibition of type II collagen-induced arthritis in rats by triptolide. Int J Immunopharmacol 20;389-400, 1998

6. Cibere J, Deng Z, Lin Y, Ou R, He Y, Wang Z, Thorne A, Lehman AJ, Tsang IK, Esdaile JM: A randomized double blind, placebo controlled trial of topical Tripterygium wilfordii in rheumatoid arthritis: reanalysis using logistic regression analysis. J Rheumatol 30;465-467, 2003

7. Yang Y, Liu Z, Tolosa E, Yang J, Li L: Triptolide induces apoptotic death of $\mathrm{T}$ lymphocyte. Immunopharmacology 40; 139-149, 1998

8. Pu LX, Zhang TM: Effects of triptolide on T lymphocyte 
functions in mice. Acta Pharmacol Sin 11;76-79, 1990

9. Kupchan SM, Court WA, Dailey RG Jr, Gilmore CJ, Bryan RF: Triptolide and tripdiolide, novel anti-leukemic diterpenoid triepoxides from Tripterygium wilfordii. J Am Chem Soc 94;7194-7195, 1972

10. Wei YS, Adachi I: Inhibitory effect of triptolide on colony formation of breast and stomach cancer cell lines. Acta Pharmacol. Sin 12;406-410, 1991

11. Chang WT, Kang JJ, Lee KY, Wei K, Anderson E, Gotmare S, Ross JA, Rosen GD: Triptolide and chemotherapy cooperate in tumor cell apoptosis: A role for the p53 pathway. J Biol Chem 276;2221-2227, 2001

12. Panichakul T, Wanun T, Reutrakul V, Sirisinha S: Synergistic cytotoxicity and apoptosis induced in human cholangiocarcinoma cell lines by a combined treatment with tumor necrosis factor-alpha (TNF-alpha) and triptolide. Asian Pac J Allergy Immunol 20;167-173, 2002

13. Lee KY, Park JS, Jee YK, Rosen GD: Triptolide sensitizes lung cancer cells to TNF-related apoptosis-inducing ligand (TRAIL)-induced apoptosis by inhibition of NF-kappaB activation. Exp Mol Med 34;462-468, 2002

14. Emoto Y, Mannome Y, Meinhardt G, Kisaki H, Kharbanda S, Robertson M, Ghayur T, WongWW, Kamen R, Weichselbaum R, Kufe DW: Proteolytic activation of protein kinase $\mathrm{C}$ delta by an ICE-like protease in apoptotic cells. EMBO J 14;6148-6156, 1995

15. Casciola-Rosen L, Nicholson DW, Chang T, Rowan KR, Thoenberry NA, Miller DK, Rosen A: Apopain/CPP32 cleaves proteins that are essential for cellular repair: a fundamental principle of apoptotic death. J Ex Med 183;1957-1964, 1996

16. Wood DE, Newcomb EW: Cleavage of bax enhances its cell death function. Exp Cell Res 256;375-382, 2000

17. Bae SS, Perry DK, Oh YS, Choi JH, Galadari SH, Ghayur T, Ryu SH, Hannun YA, Suh PG: Proteolytic cleavage of phospholipase C-gamma1 during apoptosis in Molt-4 cells. FASEB J 14;1083-1092, 2000

18. Lee KY, Chang W, Qiu D, Kao PN, Rosen GD: PG490 (triptolide) cooperates with tumor necrosis factor-alpha to induce apoptosis in tumor cells. J Biol Chem 274;1345113455, 1999

19. Hui AM, Zhang W, Chen W, Xi D, Purow B, Friedman GC, Fine HA: Agents with selective estrogen receptor (ER) modulator activity induce apoptosis in vitro and in vivo in ERnegative glioma cells. Cancer Res 64;9115-9123, 2004

20. Choi YJ, Kim TG, Kim YH, Lee SH, Kwon YK, Suh SI, Park JW, Kwon TK: Immunosuppressant PG490 (triptolide) induces apoptosis through the activation of caspase-3 and down-regulation of XIAP in U937 cells. Biochem Pharmacol 66;273-280, 2003

21. Kim YH, Lee SH, Lee JY, Choi SW, Park JW, Kwon TK: Triptolide inhibits murine-inducible nitric oxide synthase expression by down-regulating lipopolysaccharide-induced activity of nuclear factor-kappa B and c-Jun NH2-terminal kinase. Eur J Pharmacol 494;1-9, 2004

22. Bronstein DM, Perez-Otano I, Sun V, Mullis Sawin SB, Chan
J, Wu GC, Hudson PM, Kong LY, Hong JS, McMillian MK: Glia-dependent neurotoxicity and neuroprotection in mesencephalic cultures. Brain Res 704;112-611, 1995

23. Kim YS, Kennedy S, Tauber MG: Toxicity of streptococcus pneumoniae in neurons, astrocytes, and microglia in vitro. J Infect Dis $171 ; 1363-1368,1995$

24. Cheng YJ, Yang BC, Hsieh WC, Huang BM, Liu MY: Enhancement of TNF-a expression does not trigger apoptosis upon exposure of glial cells to lead and lipopolysaccharide. Toxicology 178;183-191, 2002

25. Bhat NR, Zhang P, Lee J, Hogan EL: Extracellular signal-regulated kinase and p38 subgroups of mitogen-activated protein kinases regulate inducible nitric oxide synthase and tumor necrosis factor-a gene expression in endotoxin-stimulated primary glial cultures. J Neurosc 18;1633-1641, 1998

26. Thornberry NA, Lazebnik Y: Caspases: enemies within. Science 281;1312-1316, 1998

27. Emoto Y, Mannome Y, Meinhardt G, Kisaki H, Kharbanda S, Robertson M, Ghayur T, Wong WW, Kamen R, Weichselbaum R, Kufe DW: Proteolytic activation of protein kinase $\mathrm{C}$ delta by an ICE-like protease in apoptotic cells. EMBO J 14;6148-6156, 1995

28. Lazebnik YA, Kaufmann SH, Desnoyers S, Poirer GG, Earnshaw WC: Cleavage of poly (ADP-ribose) polymerase by a proteinase with properties like ICE. Nature 371;346-347, 1994

29. Panichakul T, Wanun T, Reutrakul V, Sirisinha S: Synergistic cytotoxicity and apoptosis induced in human cholangiocarcinoma cell lines by a combined treatment with tumor necrosis factor-alpha (TNF-alpha) and triptolide. Asian Pac J Allergy Immunol 20;167-173, 2002

30. Deveraux QB, Reed JC: IAP family proteins: suppressors of apoptosis. Genes Dev 13;239-252, 1999

31. Roy N, Deveraux QL, Takahashi R, Salvesen GS, Reed JC: The c-IAP-1 and c-IAP-2 proteins are direct inhibitors of specific caspases. EMBO J 16;6914-6925, 1997

32. Deveraux QL, Leo E, Stennicke HR, Welsh K, Salvesen GS, Reed JC: Cleavage of human inhibitor of apoptosis protein XIAP results in fragments with distinct specificities for caspases. EMBO J 18;5242-5251, 1999

33. Adams JM, Cory S: The Bcl-2 protein family: arbiters of cell survival. Science 281;1322-1326, 1998

34. Sato K, Taniguchi T, Suzuki M, Shinohara F, Takada H, Rikiishi H: Dual role of NF- $\mathrm{KB}$ in apoptosis of THP-1 cells during treatment with etoposide and lipopolysaccharide. Leuk Res 28;63-69, 2004

35. Tang G, Yang J, Minemoto Y, Lin A: Blocking caspase-3-mediated proteolysis of IKK $\beta$ suppresses TNF-a-induced apoptosis. Mol Cell 8;1005-1016, 2001

36. Manna SK, Aggarwal BB: Lipopolysaccharide inhibits TNFinduced apoptosis: role of nuclear factor- $\mathrm{KB}$ activation and reactive oxygen intermediates. J Immunol 162;1510-1518, 1999

37. Thompson JE, Phillips RJ, Erdjument-Bromage H, Tempst $\mathrm{P}$, Ghosh S: IKB-regulates the persistent response in a biphasic activation of NF-kB. Cell 80;573-582, 1995 